INTERNATIONAL JOURNAL OF RESEARCHES IN BIOSCIENCES, AGRICULTURE AND TECHNOLOGY ( ) VISHWASHANTI MULTIPURPOSE SOCIETY (Global Peace Multipurpose Society) R. No. MH-659/13(N) www.vmsindia.org

\title{
A FOSSIL DICOTYLEDONOUS WOOD OF TERMINALIOXYLONCATAPPA GEN. ET. SP.NOV FROM MOHGAONKALAN, MADHYA PRADESH, INDIA. S.D. Puranik
}

Shivaji science college, nagpur sumedhadpuranik@gmail.com

\begin{abstract}
:
Fossil dicotyledonous petrified wood collected from Mohgaonkalan. Wood is porous; growth rings absent, vessels mostly solitary, large sized, multiples of two, perforation plates simple, intervascular pitting alternate bordered. Xylem parenchyma paratracheal, vasicentric, aliform, aliform confluent and metatracheal banded. Fibres non-spetate, non- storied. Rays homogenous with procumbent cells, multiseriate and rarely uniseriate. The present fossil wood shows more resemblance to the wood of Terminalia, genus of Combretaceae with close approach to Terminaliaca tappa. Hence it is named as Terminalioxylon catappaiigen. et. sp. nov.
\end{abstract}

Keywords: Dicotyledonous, fossil petrified, Combretaceae, vasicentri, monogenous.

\section{INTRODUCTION:}

Number of dicotyledonous woods have been described by different workers from the locality of Mohgaonkalan. Rode (1934) described a first petrified dicot wood from the Deccan Intertrappean Series of Mohgaonkalan under the name Parajugloxylon mohgaoense. In 1936, Rode redescribed this fossil wood in details and transferred it to the non-commital genus Dryoxylon and named it as Dryoxylon mohgaonese showing its nearest affinity with the woods of the family Combretaceae. The fossil wood under consideration also shows an approach to Combretaceae and thus is an approach report of family Combretaceae from the same exposure. The fossil wood is infected with fungal mycelium.

MATERIAL AND METHOD: the material is black in colour measuring $3.6 \mathrm{cms}$. In length and 2.5 $\mathrm{cms}$ in breadth. The preservation is fine regarding cellular details. The material is studied by taking the peel section along T.S., T.L.S. and R.L.S. plane.

Description: It is diffuse porous dicot wood, showing secondary growth, growth rings being absent. Pith is not preserved. Wood consist of vessels, xylem parenchyma, canals, wood fibres and wood rays.

Vessels: Vessels are large, mostly solitary and few are in oblique multiples of two (Plate 1, Fig. 1). Rarely clustering of vessels is seen. These measures $200 \mu$ to $300 \mu$ in tangential diameter. Frequency of vessels is 4 to 10 per sq. mm. Vessel member is moderately long, its length being 900 $\mu$. Some vessels members are filled with dark brown contents (Plate 3, Fig. 1, 2). Intervascular pitting is alternate, bordered, hexagonal with oval pore (Plate 3, Fig. 2). The pore measures $6.2 \mu$ in diameter. Some of the vessels are contiguous with rays on one or both the sides (Plate 1, fig. 2,3,4). Vessels are filled with dark brown to black coloured depositions (Plate 1, Fig. 1,2,3). Fungal mycelium is seen in lumen of most of the vessels.

Xylem Parenchyma: It is paratracheal vasicentric, about 1-3 layers around each vessel (Plate 1, Fig. 2). Aliform and aliform confluent parenchyma is also present (Plate 1, Fig. 4,5,6). Metatracheal bands of parenchyma are clearly seen (Plate 1, Fig. 3).

Canals: Gum canals are present which are embedded in parenchyma in uniseriate tangential rows at irregular intervals (Plate 2, Fig. 1,2). Each canal is more or less elongated and measure 225 $\mu$ in length and $122 \mu$ in breadth. Each canal is lined by thin walled parenchyma epithelial cells (Plate 2, Fig. 3). The inner boundary of the canal is irregular due to pressure during preservation. The canals shows yellowish to dark brown contents (Plate 2, Fig. 3).

Wood Fibres: These forms a major mass of wood (Plate 1,Fig 1,2,3). In transverse section these are squarish to angular in shape. They are nonstored and aseptate (Plate 3, Fig. 1). Fibres are long, their length being $60 \mu$ to $200 \mu$ and breadth varies from $17 \mu$ to $25 \mu$.

Wood Rays: Rays are homogeneous, being made of procumbent cells only (Plate 2, Fig. 4,5 and Plate 3, Fig. 1). These are uniseriate to multiseriate (Plate 2, Fig. 4,5). Riseriate to pentaseriate rays are more common. Wood rays frequency is 4 to 8 per $\mathrm{mm}$. The height of ray is $800 \mu$ to $2500 \mu$ and breadth is about $100 \mu$ to $120 \mu$. Rays are both separate and contiguous 
with vessels pits on rays cells are alternate and bordered (Plate 3, Fig. 3).

IDENTIFICATION: from the above description it is clear that the specimen under investigation shows the following important anatomical characters which are of great help in its identification:

1. Presence of diffuse porous wood.

2. Presence of large sized vessels.

3. Vessels are mostly solitary and sometimes in oblique multiples of two only and few in clusters of 3-4.

4. Vessels are with alternate, bordered piths.

5. Perforation plate is simple, transversely and rarely obliquely placed.

6. Xylem parenchyma is paratracheal vasicentric, aliform, aliform confluent and metatracheal banded.

7. Fibres are non-spetate and non-storied.

8. Rays are homogenous and made up of procumbent cells only. They mostly multiseriate and very few uniseriate.

9. Presence of canals.

For identification of the present fossil wood, key given by Metcalfe and Chalk (1950), Shallom (1963) and Esau (1965) are used. The characters of the specimen mentioned above suggest its relationship with the woods of the following families:

-Caesalpinaceae

- Celastraceae

- Combretaceae

The present fossil wood resembles the wood of Caesalpinaceae, in having vessels mostly solitary, with a few small multiples and simple perforation plate. Intervascular pitting is alternate. Parenchyma is paratracheal and confluent band. However, present wood differ from Caesalpinaceae in following characters:

- Parenchyma in the fossil specimen is vasicentric, aliform confluent and metatracheal banded ( Paratracheal and irregular confluent band in Caesalpinaceae).

- Rays are multiseriate (exclusively uniseriate in Caesalpinaceae).

It resembles Celastraceae in having vessels mostly solitary, arrangement of parenchyma and in nature of fibres. However, present wood differs from Celastraceae in the following characters:

- Vessels are large (small in Celastraceae).

- Rays are uni and multiseriate (exclusively uniseriate in Celastraceae).

After eliminating Caesalpinaceae and Celastraceae, the fossil woodresembles the woods of family Combretaceae in the following:

- Presence of mostly solitary vessels.
-Presence of simple perforation plate with alternate bordered pits.

-Absence of tylosis.

-Presence of aliform to confluent parenchyma and also vasicentric and metatracheal banded parenchyma.

- Presence of homogenous rays.

-Presence of non septate fibres in some genera. When affinities are traced with genera of this family, wood is seen nearer to the living genus Terminalia (Linn.). over 200 species have been described which are widely distributed throughout tropical and subtropical regions in both hemisphere (Pearson and Brown, 1932). The wood resembles Terminalia (Pearson and Brown, 1932) in following characters:

-In size of vessels

-In nature of parenchyma

- Intervascular pitting alternate and bordered

-Perforation plate simple

-Absence of tylosis

-In having nonseptate fibres

- Rays homogenous and 1-5 seriate

-Presence of gum canals

-An anatomical features worthy of note is presence of Intraxylary phloem at the margin of the pith in Terminalia (Pearson and Brown, 1932) but in fossil material, pith portion is not preserved. Hence comparison in this could not be done.

The Indian Almond family is represented in India by 6 genera and over 40 species. Terminalia includes 12 species (Pearson and Brown, 1932). Out of 12 species the present fossil wood is comparable with $T$. catappa (Linn.).

It is a large tree present along the seashore in Tenasserin and of all the Andaman Islands. Similarities with T. catappa are-

1. Vessels very large to medium sized.

2. Presence of mostly solitary vessels.

3. In frequency of vessels (2-14 per $\mathrm{mm}$ ).

4. Length of vessel segment (approximate 700$900 \mu)$.

5. Nature of perforation plate i.e, simple, horizontal and oblique.

6. In presence of bordered pits to vessels.

7. In absence of tylosis.

8. Presence of gummy depositions in the vessels.

9. Paratracheal parenchyma abundant.

10. Presence of gum canals in parenchyma in uniseriate row.

11. Presence of metatracheal parenchyma.

12. Fibres mostly aseptate.

13. Diameter of fibres $(17-25 \mu)$.

14. Frequency of rays (5-8 per $\mathrm{mm})$. 
15. Rays 1-5 seriate, homogenous.

16. Presence of contents in rays.

17. Gum canals present which are embedded in parenchyma in uniseriate tangential row at irregular interval.

18. Contents of canal reddish brown.

An attempt is made to compare the present fossil wood with thefossil woods of Combretaceae.

-Dryoxylon mohgaoense Rode (U. Prakash, 1957a ) and

-Anogeissusoxylon mohgaoense (Patil, 1976).

The present fossil wood resembles Dryoxylon mohgaoense in the following characters:

-Absence of growth ring.

-Presence of mostly solitary vessels and in pairs.

-Perforation are simple.

- Rays usually homogenous.

-Fibres are non-septate.

But the present fossil wood differs from Dryoxylon mohgaoense in the following characters:

-Absence of Tylosis (presence of tylosis in Dryoxylon mohgaoense).

-Presence of alternate and bordered intervascular pitting. (vestured inter vascular pitting in Dryoxylon mohgaoense).

-Parenchyma paratracheal, vasicentric, aliform, confluent and metatracheal banded (parenchyma typically scanty and paratracheal in Dryoxylon mohgaoense).

-Xylem rays uniseriate to multiseriate and triseriate to pentaseriate are most common (Xylem rays mostly uniseriate and rarely biseriate in Dryoxylon mohgaoense).

The present fossil wood resembles Anogeissusoxylon mohgaonese in the following characters.

-Presence of solitary vessels.

-Presence of simple and transverse perforation plate.

- Presence of alternate pits in vessel.

-Presence of paratracheal, vasicnetric, aliform and metatracheal banded parenchyma.

-Presence of non-storied fibres.

But present fossil wood differs from Anogeissusoxylon mohgaonese in following characters.

-Total absence of tylosis (Rarely presence of tylosis in Anogeissusoxylon mohgaonese).

-Presence of large vessels in fossil specimen (Vessels are very small sized i.e, $80-100 \mu$ in tangential diameter in Anogeissusoxylon mohgaonese).

- Presence of aliform confluent parenchyma (It is absent in Anogeissusoxylon mohgaonese).
- Presence of non-septate fibres (Fibres are septate in Anogeissusoxylon mohgaonese).

- Presence of homogenous rays (Rays are heterogeneous in Anogeissusoxylon mohgaonese ).

It is evident from above discussion that the present fossil wood shows more resemblance to the wood of Terminalia (genus Combretaceae) with close approach to Terminaliaca tappa. Hence it is named as Terminalioxylonca tappa gen. et. sp. nov. The generic name being after genus Terminalia and specific name is after species catappa.

\section{DIAGNOSIS:}

Terminalioxylon gen. nov.

Wood diffuse porous; growth rings absent, vessels large sized mostly solitary and in oblique multiples of two only and rarely $3-4$ cells in clusters. Tylosis absent. Perforation plate simple; transversely and rarely obliquely placed. Intervascular pitting alternate bordered. Xylem parenchyma paratracheal, vasicentric, aliform, aliform confluent and metatracheal banded. Uniseriate gum canals. Rays homogenous and 15 seriate. Fibres non-septate and non- storied.

Terminalioxylonca tappa gen. et. sp. nov.

Xylem vessels mostly solitary, scattered all over and some in oblique multiples of two only and rarely clusters of 3-4 cells. Vessels larged sized. These measures $200 \mu-300 \mu$ in tangential diameter. The frequency of vessels 4-10 per. Sq.mm. perforation plate simple, transversely and rarely obliquely placed. Intervascular pitting alternate, bordered, xylem parenchyma paratracheal vasicentric, aliform, aliform confluent and metatracheal vascentric, aliform, aliform confluent and metatracheal banded. Vasicentric parenchyma consist of 2-3 layers around vessels. Fibres non-spetate, non- storied $60 \mu$ to $200 \mu$ in height and breadth varies from $17 \mu$ to $25 \mu$, niseriate canals with parenchyma, $225 \mu$ in length and $122 \mu$ in breadth. Rays homogenous with procumbent cells only. Rays are multiseriate and rarely uniseriate. Frequency of rays is $4-r$ per mm. Height of rays is $800 \mu$ to $2500 \mu$ and breadth is about $100 \mu$ to $200 \mu$.

Holotype: Deposited in the Department of Botany, Institute of Science, Nagpur.

Locality: Mohgaonkalan, Chhindwara district, Madhya Pradesh, India.

Horizon: Deccan Intertrappean series of India.

Age: ? Uppermost cretaceous to Palaeocene.

\section{Explanation of Plate 1}


- $\quad$ Fig. 1: T.S. of wood showing distribution of solitary vessels few in multiple, rays and fibres. X 155

- Fig. 2: T.S. of wood showing vessels with vasicentric paratracheal parenchyma and uni, bi and multiseriate rays with content. $\mathrm{X}$ 155

- Fig. 3: T.S. of wood showing vessels with metatracheal banded and vasicentric paratracheal parenchyma and multiseriate rays. $\mathrm{X} 155$

- Fig. 4: T.S. of wood showing vessels with aliform confluent parenchyma. X 155

- Fig. 5: T.S. of wood showing vessels with aliform confluent parenchyma. X 155

- Fig. 6: Vessels with aliform confluent parenchyma. X 155

\section{Explanation of Plate 2}

- Fig. 1: T.S. of wood showing vessels, multiseriate rays and gum canals in uniseriate tangential row with content. X155

- Fig. 2: Tangential row of canals embedded in parenchyma. X 155

- $\quad$ Fig. 3: A single canal (magnified) lined by thin walled parenchymatous epithelial cells. X 580

- $\quad$ Fig. 4: T.L.S. of wood showing triseriate and multiseriate rays and fibres. X 155

- Fig. 5: T. L. S. of wood showing uniseriate, biseriate, triseriate and multiseriate rays and fibres. X 155

\section{Explanation of Plate 3}

- Fig. 1: R.L.S. of wood showing vessel with simple perforation plate, homogenous ray cells and nonstored, aspetate fibres. X 155

- $\quad$ Fig. 2: Vessel (magnified) with simple, slightly obliquely placed perforation plate and alternate, bordered intervascular pitting. $\mathrm{X}$ 580

- Fig. 3: R.L.S. of wood showing ray cells (magnified) with alternate, bordered pitting. X 580

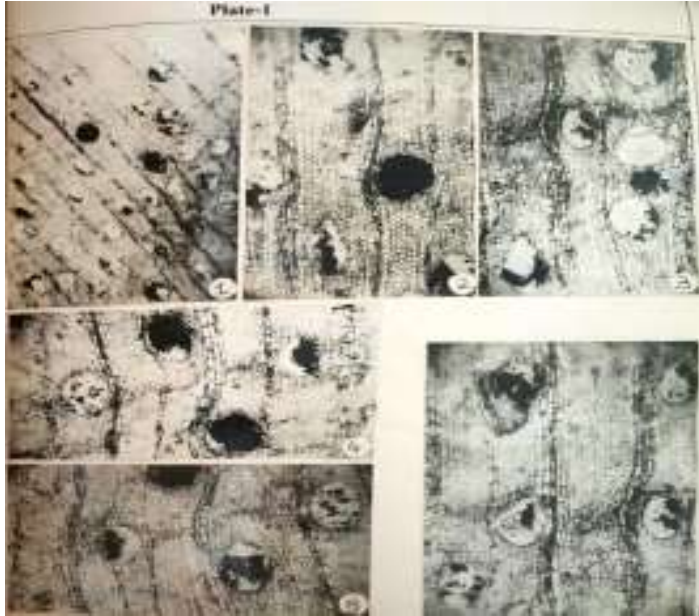

Terminalioxylonca tappagen. et. sp. nov.

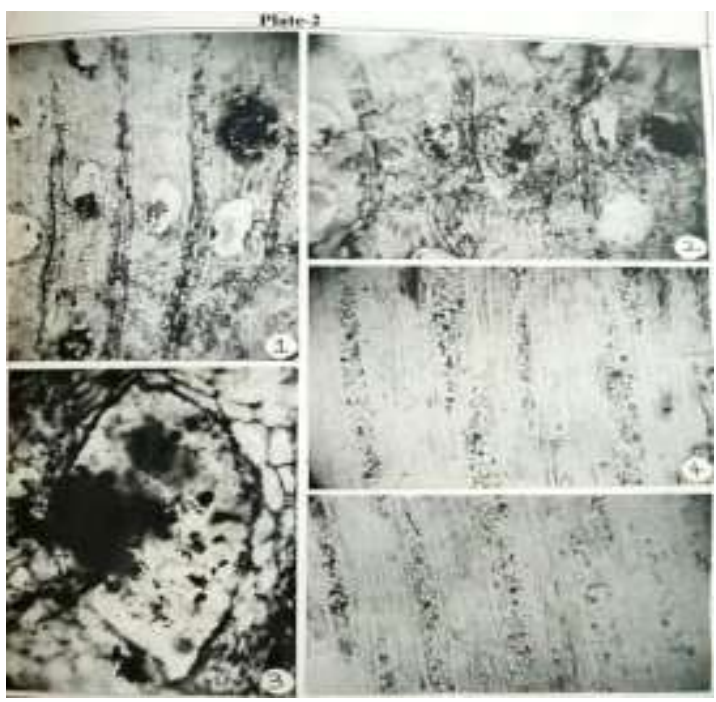

Terminalioxylonca tappa gen. et. sp. nov.

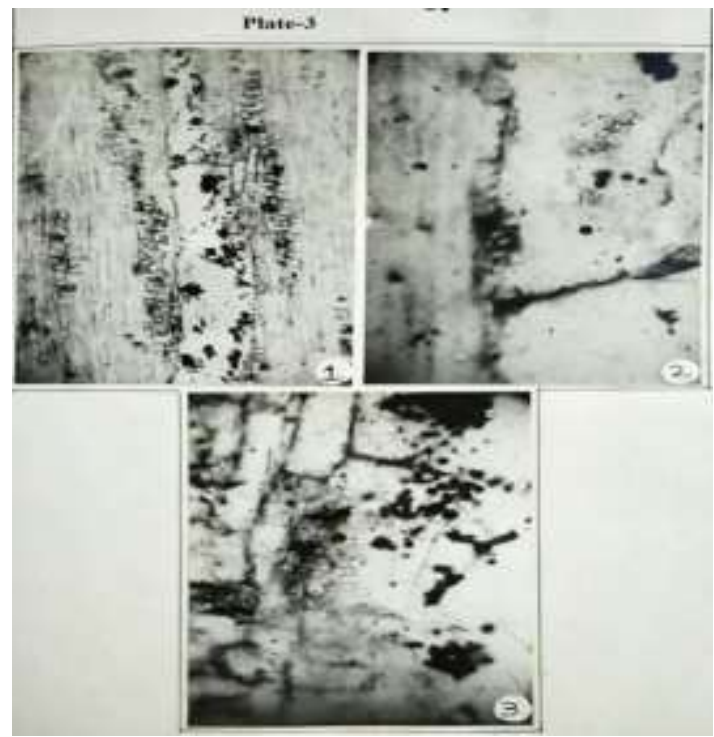




\section{References:}

Esau, Katherine (1965). Plant Anatomy. Wiley International edition (sec. ed) Toppan Company, limited, Tokyo, Japan.

Hislop S. (1853). Remarks on the geology of Nagpur. J. Bomb. Asiat. Soc. 5:58-67

Hislop S. (1854). Remarks on geology of Nagpur J. Geol.soc. London . 11:356.

Hislop S. and Hunter R. (1854). A sketch of the geology of Nagpur. Cuart. Jour. Geol. Soc. 10:470-473.

Hislop S. and Hunter R. (1855). On the geology and fossil of neighborhood of Nagpur, central India. Cuart. J. Geol.Soc. London. 11(3): 354-383.

Metcalfe, C.R. and Chalk, L. (1950). Anatomy of the Dicotyledonous I and II Oxford University Press Great Britain.

Patil, G.V. (1976). Anogeissusoxylonmohgaonese studies in
Deccan Intertrappean Flora of India, Page 138, Ph.D Thesis, Nagpur University, Nagpur.

Pearson, R.S and Brown, H.P. (1932). Commercial Timbers of India. Calcutta.

Prakash, U. (1957 a). Studies in Deccan Intertrappean Flora, 2 Further Observation on Dryoxylonmohgaoense, Rode, Paleobotanist, 5(2): 104-108.

Rode, K.P. (1936). A silicified dicotyledonous wood, Dryoxylonmohgaoense sp. nov. From the Deccan Intertrappean beds of India. J. Ind. Bot. Soc. 15(2) : 131-138.

Sahni B. (1934). Silicified flora of the Deccan series - Part II. Gymnospermous and Angiospermous fruits. Proc. 21 $1^{\text {st }}$ Indian Sci. Cong. Bombay. Abst. 3: 317-318.

Shallom, L.J. (1963). Contribution to the knowledge of the Deccan Intertrappean flora of India. Ph.D Thesis, Nagpur University, Nagpur. 